\title{
Bid protects the mouse hematopoietic system following hydroxyurea-induced replicative stress
}

\author{
Y Liu', A Aiello² and SS Zinkel ${ }^{*, 1,2}$
}

Hematopoietic stem cells (HSCs) possess long-term self-renewal capacity and multipotent differentiative capacity, to maintain the hematopoietic system. Long-term hematopoietic homeostasis requires effective control of genotoxic damage to maintain HSC function and prevent propagation of deleterious mutations. Here we investigate the role of the BH3-only Bcl-2 family member Bid in the response of murine hematopoietic cells to long-term replicative stress induced by hydroxyurea (HU). The PI3-like serine/threonine kinase, ATR, initiates the DNA damage response (DDR) to replicative stress. The pro-apoptotic Bcl-2 family member, Bid, facilitates this response to replicative stress in hematopoietic cells, but the in vivo role of this DDR function of Bid has not been defined. Surprisingly, we demonstrate that long-term HU treatment expands wild-type myeloid progenitor cells (MPCs) and HSC-enriched $\mathrm{Lin}^{-} \mathrm{Sca}^{+} \mathrm{Kit}^{+}$(LSK) cells to maintain bone marrow function as measured by long-term competitive repopulating ability. Bid - I- MPCs demonstrate increased sensitivity to HU and are depleted. Bid - I - LSK cells demonstrate increased mobilization manifest by increased Bromodeoxyuridine (BrdU) incorporation. Bid - / - MPCs and LSK cells are relatively depleted, however, and bone marrow from Bid $-I-$ mice demonstrates decreased long-term competitive repopulating ability in both primary and secondary transplants. We thus describe a survival function of Bid in hematopoiesis in the setting of chronic replicative stress.

Cell Death and Differentiation (2012) 19, 1602-1612; doi:10.1038/cdd.2012.38; published online 20 April 2012

Hematopoietic stem cells (HSCs) are the multipotent cells that maintain the entire blood system over the lifespan of an organism. ${ }^{1-3}$ HSCs are subject to genotoxic stress through both extrinsic sources such as environmental toxins and radiation, as well as DNA damage arising from essential functions of the cell, such as during DNA replication. The central hematopoietic maintenance role of HSCs requires stringent protection of genomic integrity.

The dynamic nature of the hematopoietic system places it in a vulnerable position with respect to genomic damage during DNA replication. ${ }^{4}$ Following hematopoietic stress, HSCs are mobilized, and enter the cell cycle to produce the rapidly cycling hematopoietic progenitors that replenish the hematopoietic compartment. Thus, both the HSCs as well as the committed progenitors are vulnerable to replicative stressinduced DNA damage. Indeed, defects in cell cycle checkpoints result in excessive mobilization of HSCs, depleting HSC self-renewal function in bone marrow transplantation. ${ }^{5}$

Recently, two groups investigated the response of HSCs and committed progenitor cells to DNA damage induced by ionizing radiation (IR) in mouse and human systems, respectively. ${ }^{6,7}$ Murine hematopoietic stem and progenitor cells (HSPCs: lin ${ }^{-} / \mathrm{c}_{-} \mathrm{kit}^{+} / \mathrm{Sca}-1^{+} / \mathrm{Flk} 2^{-}$) resist IR-induced apoptosis and preferentially utilize error-prone non-homologous end joining for DNA repair. ${ }^{6}$ Human HSPCs isolated from human cord blood upregulate p53 in response to DNA damage and are removed by apoptosis. ${ }^{7}$ In both systems, HSCs appear to maintain long-term genomic integrity at the expense of repopulating ability. The impact of chronic replicative stress on bone marrow function has not been evaluated.

A highly regulated signaling program activates cell cycle checkpoints, DNA repair, and apoptosis in response to DNA damage. The PI3-like kinase Ataxia Telangiectasia Mutated (Atm) initiates the DNA damage response (DDR) to doublestrand breaks (DSBs) induced by agents such as IR. ${ }^{8}$ The Ataxia telangiectasia and RAD3 related (Atr) DNA damage kinase mediates the DDR to single-stranded DNA generated during replicative stress. The ribonucleotide reductase inhibitor hydroxyurea $(\mathrm{HU})$ stimulates the Atr-directed DDR by depleting nucleotide pools, resulting in stalled replication forks. Atr is also essential for DNA replication. ${ }^{9-11}$ Cells with

\footnotetext{
${ }^{1}$ Department of Cell and Developmental Biology, Vanderbilt University Medical Center, Nashville, TN, USA and ${ }^{2}$ Department of Medicine, Vanderbilt University Medical Center, Nashville, TN, USA

${ }^{*}$ Corresponding author: SS Zinkel, Department of Medicine, Vanderbilt University Medical Center, 548 PRB, VUMC, Nashville, TN 37232 , USA. Tel: + 1615 936 1801; Fax: + 1615936 3853; E-mail: Sandra.zinkel@ vanderbilt.edu

Keywords: Bid; DNA damage response; hematopoiesis; Bcl-2 family

Abbreviations: Atm, ataxia telangiectasia mutated; Atr, Atm and Rad3-related; Bid, BH3 interacting domain death agonist; BrdU, bromodeoxyuridine; $\mathrm{CD}$, cluster of differentiation; CMML, chronic myelomonocytic leukemia; CMP, common myeloid progenitor; DDR, DNA damage response; DNA, deoxyribonucleic acid; DSBs, DNA double-strand breaks; GEMM, colony forming unit of granulocyte/erythrocyte/macrophage/megakaryocyte; GM, colony forming unit of granulocyte/macrophage; GMP, granulocyte-macrophage progenitor; HSC, hematopoietic stem cell; HSPCs, hematopoietic stem and progenitor cells; HU, hydroxyurea; IL3, interleukin 3; IR, ionizing radiation; LSK, Lin - Sca1 + Kit + ; MEP, megakaryocyte-erythrocyte progenitor; MPCs, myeloid progenitor cells; PIKKs, phosphoinositide 3-kinaserelated protein kinases; RPA, replication protein A

Received 10.11.11; revised 20.2.12; accepted 28.2.12; Edited by P Bouillet; published online 20.4.12
} 
defects in the Atr pathway show increased sensitivity to DNAdamaging agents causing replicative stress such as $\mathrm{HU} .^{12,13}$

A number of key factors in the DNA damage/repair pathways have an important role to maintain genomic integrity and bone marrow function. Atr conditional knockout mice demonstrate premature aging defects with significantly decreased LSK populations and thymic progenitors. ${ }^{14}$ Atm - / - mice demonstrate progressive bone marrow failure due to a depletion of LSK cells, as well as HSC function. ${ }^{15}$ Mice harboring a hypermorphic mutant allele of p53 display a reduced proliferating HSC population in aging with limited HSC function. ${ }^{16}$ In addition, mice with deficiencies in DNA repair, including nucleotide excision repair, telomere maintenance, and non-homologous end-joining, have diminished hematopoietic stem cell function with age,${ }^{17,18}$ suggesting that the accumulation of endogenous DNA damage limits stem cell function in a cell autonomous fashion.

Pro-apoptotic Bid is highly expressed in the hematopoietic system and regulates myeloid homeostasis and tumorigenesis. ${ }^{19,20}$ Bid is a highly potent activator of intrinsic apoptosis following multiple cellular stresses; ${ }^{21-25}$ however, a singular apoptotic function does not account for all of the current data regarding Bid's function. Bid-deficient myeloid progenitor cells (MPCs) display decreased viability in culture. ${ }^{19,20}$ Cultured Bid-I - activated T cells and myeloid progenitor cells are hypersensitive to $\mathrm{HU}$ but not IR treatment in vitro. ${ }^{26} \mathrm{Bid}-1-$ bone marrow is hypersensitive to intraperitoneal injection of $\mathrm{HU}$ but not to IR in vivo, ${ }^{19}$ consistent with an impaired DDR to replicative stress. Indeed, Bid-/- MPCs and Bid-deficient U2OS cells demonstrate limited Atr function following $\mathrm{HU}$ treatment. ${ }^{19}$ Furthermore, Bid associates with the Atr/Atrip/ RPA complex, ${ }^{19}$ and the association between Atr/Atrip and RPA is significantly diminished in Bid-deficient cells following replicative stress, ${ }^{19}$ suggesting that Bid has a role to maintain the DNA damage sensor complex. Bid is thus positioned to have a role in the DDR response to replicative stress in the hematopoietic system.

In this study, we investigated the in vivo response of wild type and Bid-I- LSK cells and committed progenitors to replicative stress. Interestingly, in wild-type mice under conditions of repeated replicative stress, the LSK and MPC cell populations are expanded, and the bone marrow function is maintained as demonstrated by the ability to compete with unchallenged bone marrow to adequately repopulate lethally irradiated recipient mice. Thus, LSK and MPC cell populations expand to maintain homeostatic control.

Consistent with a role for Bid in the DDR to replicative stress, Bid-/- hematopoietic progenitor cells demonstrate increased cell death and increased DNA damage. This increased progenitor cell death leads to increased Bid-I - LSK cell proliferation during replicative stressinduced homeostatic recovery. Following long-term $\mathrm{HU}$ treatment, the HSC-enriched LSK and myeloid progenitor cell populations are significantly diminished in Bid-/ - mice and $\gamma \mathrm{H} 2 \mathrm{~A}$.X-positive cells are significantly increased in Bid-I - bone marrow. In addition, long-term HU-stressed Bid-/ - bone marrow displays defective primary and secondary repopulating ability, consistent with diminished stem cell function. Our studies are most consistent with Bid facilitating normal Atr function to maintain replication fork and genomic integrity in the cycling progenitor cells following replicative stress. Proper control of replicative-stress-induced progenitor cell death thus prevents excessive mobilization of HSCs and depletion of bone marrow function.

\section{Results}

MPC but not LSK cell populations are decreased in mouse bone marrow following $\mathrm{HU}$ treatment. Over the lifetime of an organism, replicative stress damages DNA of bone marrow progenitor cells. To investigate the role of Bid on bone marrow function in the setting of chronic replicative stress, we treated $\mathrm{Bid}+/+$ and $\mathrm{Bid}-/-$ mice with $\mathrm{HU}$ to deplete nucleotide pools, thus selectively depleting the replicating MPCs. HU treatment has been demonstrated to increase cycling of the HSC-enriched LSK population in vivo, ${ }^{27}$ presumably by mobilization of HSCs to replenish depleted progenitor cell populations. Bid-/- mice were chosen as a model to investigate the physiological function of ATR-mediated DDR in the hematopoietic system.

$\mathrm{Bid}+/+$ and Bid-I- mice were treated with $\mathrm{HU}$ by intraperitoneal injection for 3 consecutive days and the regulation of hematopoiesis was studied. LSK (Lin - Sca1+ $\mathrm{cKit}^{+}$) and MPC ( $\left.\mathrm{Lin}^{-} \mathrm{Scal}^{-} \mathrm{CKit}^{+}\right)$cells were evaluated by immunostaining and flow cytometry. ${ }^{28}$ The lineage (Lin) cocktail consisted of: CD3, B220, Ter119, Gr-1. Lin ${ }^{-}$, c-kit ${ }^{+}$, Sca-1 ${ }^{-}$cells were stained for CD34 and Fc $\gamma / 1 / I I I$ to delineate subpopulations of progenitor cells. LSK cells were defined as Lin $^{-}$, c-kit ${ }^{\text {high }}$, Sca-1 ${ }^{\text {high }}$. Megakaryocyte-erythroid progenitors (MEPs) were defined as $\mathrm{Lin}^{-} \mathrm{c}-\mathrm{kit}^{\text {high }} \mathrm{Sca}-1^{\text {low }} \mathrm{CD} 34^{-}$ $\mathrm{Fc} \gamma \mathrm{Il} / \mathrm{III}^{\mathrm{lo}}$, granulocyte-macrophage progenitors (GMPs) were defined as Lin $^{-} \mathrm{c}-\mathrm{kit}^{\text {high }} \mathrm{Sca}-1^{\text {low }} \mathrm{CD} 34^{+} \mathrm{Fc} \gamma \mathrm{II} / \mathrm{III} \mathrm{I}^{\text {high }}$, and common myeloid progenitors (CMPs) were defined as $\mathrm{Lin}^{-} \mathrm{c}-\mathrm{kit}^{\text {high }} \mathrm{Sca}-1^{\text {low }} \mathrm{CD} 34^{+} \mathrm{Fc} \gamma \mathrm{Il} / \mathrm{III}^{\mathrm{lo}}$. Following $\mathrm{HU}$ treatment, the MPC populations (CMP, GMP, MEP) were significantly diminished in Bid-I- bone marrow (Figures $1 \mathrm{a}$ and $\mathrm{b}$ ), which is consistent with our previous finding that cultured $\mathrm{Bid}-\mathrm{I}-\mathrm{MPCs}$ are hypersensitive to $\mathrm{HU}{ }^{26}$ Interestingly, no obvious alteration was observed in the HSC-enriched LSK population (Figure 1c).

Apoptosis is increased in both the MPC and LSK populations in Bid $-I-$ but not Bid $+I+$ bone marrow. To investigate Bid's role in the apoptotic response of MPCs and LSK cells to replicative stress, Bid +/+ and Bid-Imice were injected with $100 \mathrm{mg} / \mathrm{kg} /$ day HU intraperitoneally daily for 3 days, and the bone marrow was analyzed by flow cytometry on day 4 . Using this treatment schedule, Bid-Ibone marrow demonstrated significantly increased Annexin V-positive MPC and LSK cells following $\mathrm{HU}$ treatment (Figures $2 \mathrm{a}$ and $\mathrm{b}$ ) relative to $\mathrm{Bid}+/+$ MPC and LSK cells.

Bid-/- LSK cell populations demonstrate increased bromodeoxyuridine (BrdU) incorporation. To investigate the proliferation of MPCs and LSKs following $\mathrm{HU}, \mathrm{Bid}+/+$ and Bid-I- mice were treated with $\mathrm{HU}$ as above. Mice were injected with BrdU $23 \mathrm{~h}$ after the last $\mathrm{HU}$ treatment. Following HU, both LSK and MPC populations demonstrate significantly increased BrdU incorporation compared with untreated mice (Figures $2 c$ and $d$ ), which is consistent 

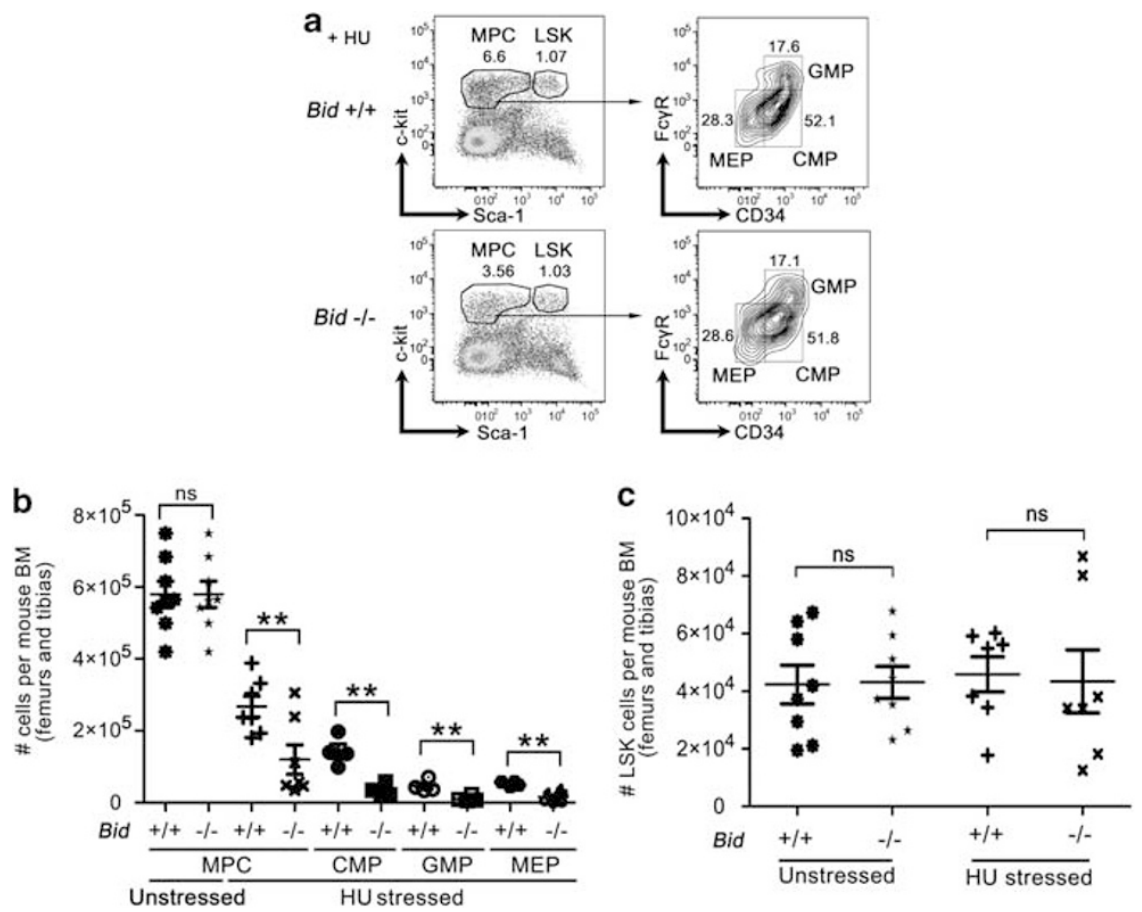

Figure 1 Bid - / - MPC but not LSK cell population is diminished following HU treatment. (a) Bid $+/+$ and Bid - / - mice were treated with HU for 3 consecutive days and bone marrow was harvested from femurs and tibias $24 \mathrm{~h}$ after the third injection. Cells were first stained with lineage marker (biotinylated CD3, B220, Gr-1 and Ter119) and then stained with c-kit, Sca1, CD34 and FcyRII/III. MPC and LSK cells were defined as Lin - Sca1 - ckit + and Lin - Scal + ckit + population, respectively. GMP, CMP, and MEP cells were defined as CD34 + Fc $\gamma R+, C D 34+F c \gamma R-$, and CD34 - Fc $\gamma R-$ population from MPC cells, respectively. Representative flow plots were shown. (b) Quantitative analysis of MPC, CMP, GMP and MEP cell populations. (c) Quantitative analysis of LSK cell population. $n=7$; ${ }^{* *} P<0.01$ (Statistical analysis was performed by a two-sample Student's t-test). Error bar, S.E.M.

with mobilization of bone marrow progenitor cells to replenish cells depleted by HU. ${ }^{27}$ Interestingly, HU-stressed LSK but not MPC populations in Bid - / - bone marrow demonstrated significantly increased BrdU incorporation (Figures 2c and d). Augmented loss of MPCs following $\mathrm{HU}$ in $\mathrm{Bid}-/$ - mice thus increases proliferation of LSK cells.

HU-stressed Bid-I- bone marrow forms abnormal immature colonies in methylcellulose culture. To further evaluate colony-forming ability of $\mathrm{Bid}-/$ - bone marrow following $\mathrm{HU}$, bone marrow from $\mathrm{HU}$-stressed $\mathrm{Bid}+/+$ and Bid - I - mice was harvested and cultured in methylcellulose supplemented with interleukin 3 (IL3), interleukin 6 (IL6), stem cell factor (SCF), and erythropoietin (EPO). These conditions support differentiation of hematopoietic cells through the myeloid lineage. Colony morphology reflects the cell types in the colony, and thus reflects the differentiative capacity of the cell of origin. ${ }^{28,29}$ GEMM colonies (colonyforming unit of granulocyte/erythrocyte/macrophage/megakaryocyte) are formed from HSCs and CMP cells; GM colonies (colony-forming unit of granulocyte/macrophage) are formed from granulocyte-macrophage progenitor (GMP) cells; $\mathrm{G}$ and $\mathrm{M}$ colonies are generated from granulocyte and macrophage, respectively. ${ }^{1}$ Strikingly, huge GEMM colonies were observed in Bid-I - cultures on day 4 after the bone marrow was plated (Figures $2 e$ and f), consistent with the increased proliferation noted in Bid-/ - LSK cells and MPCs. In addition, immature colonies (GEMM and GM colonies) but not mature colonies ( $\mathrm{G}$ and $\mathrm{M}$ colonies) were significantly increased in Bid-/- methylcellulose cultures (Figures $2 \mathrm{~g}$ and $\mathrm{h}$ ).

To evaluate the self-renewal/proliferative capacity of $\mathrm{HU}$-stressed bone marrow, methylcellulose cultures were serially replated at 7-day intervals. Interestingly, Bid - / - but not $\mathrm{Bid}+\mathrm{I}+$ bone marrow displayed a prolonged colony forming ability (Figures $3 a, b$ and $4 b$ ). Of note, the colony numbers reflect the numbers of progenitor cells that persist, and are therefore a measure of both cell viability as well as differentiation status. The colony numbers demonstrate an initial decline followed by an increase upon serial replating. This 'wave effect' is highly reproducible and is commonly observed in serial replating studies. ${ }^{30,31}$ Cytospin analysis of bone marrow cells after the third methylcellulose plating demonstrated increased progenitor cells in Bid-/- cultures (Figure 4a). The black arrow denotes a neutrophil, the terminally differentiated myeloid cell type. The yellow arrow denotes a myelocyte, an immature myeloid cell type. Unstressed Bid-/- bone marrow demonstrates increased colonies relative to $\mathrm{Bid}+/+$ bone marrow, most notable in the third plating, but ultimately it is exhausted after the fourth plate (Figure $3 \mathrm{c}$ ). These results demonstrate that Bid-Iimmature HSC/MPC populations persist in methylcellulose cultures, suggesting that they may possess an abnormal proliferative potential and/or decreased apoptosis ex vivo following HU stress.

Bid is also a substrate of Atm, the DNA damage kinase directing the DDR to IR. Notably, Atm - / - bone marrow HSC and progenitor cells are more sensitive to IR. This difference, 
a

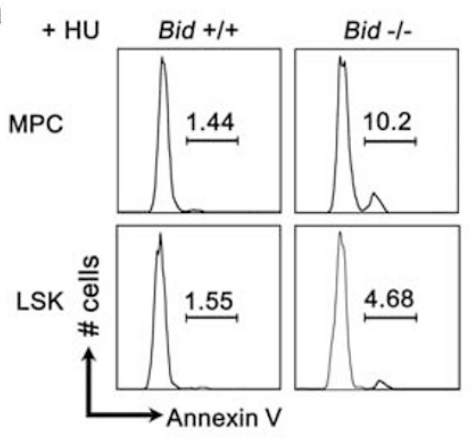

C

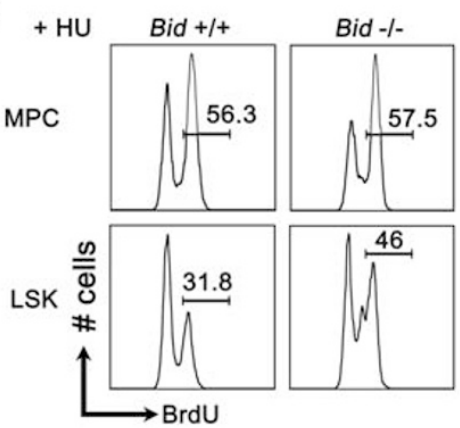

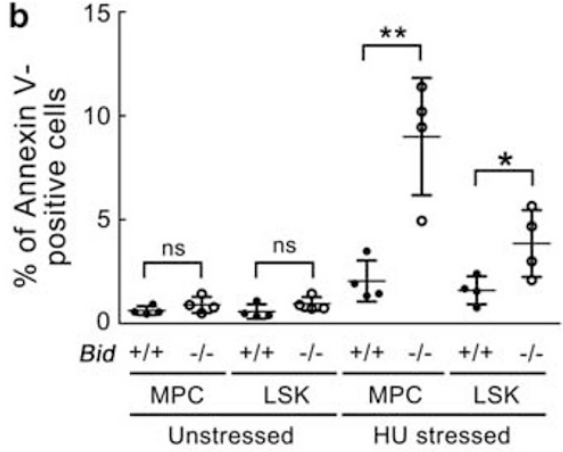

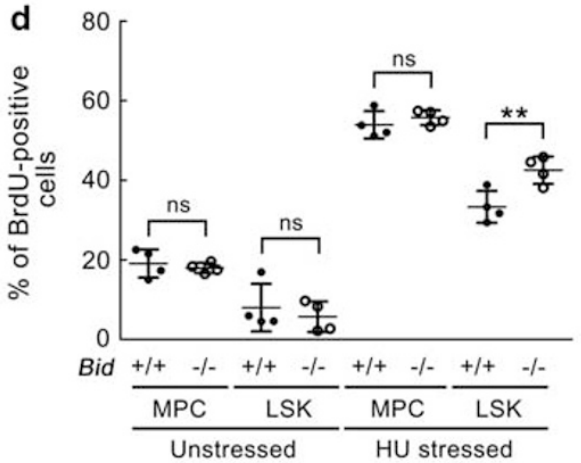

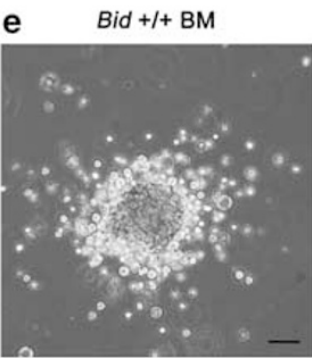

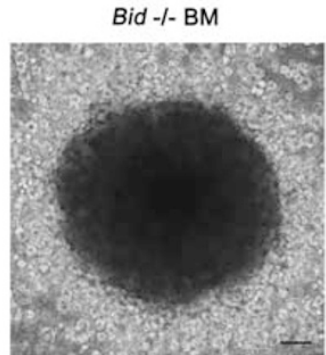

$-100 \mu \mathrm{m}$ f

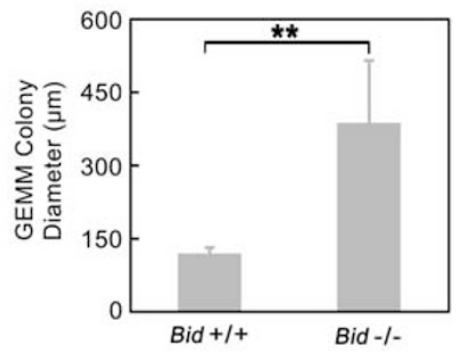

g

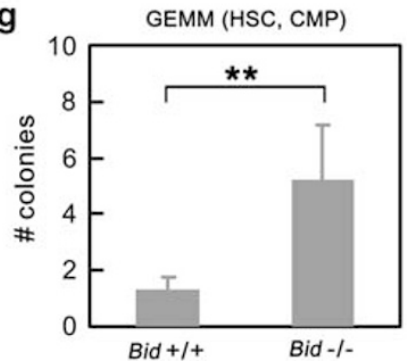

h

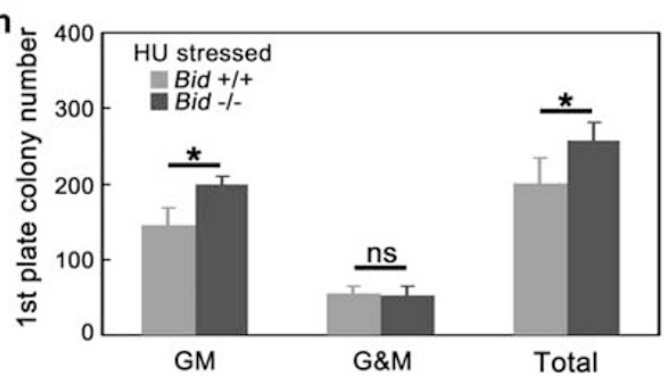

Figure 2 Cycling and apoptotic LSK cell populations are increased in Bid - / - bone marrow following HU treatment. (a) Bid + / + and Bid - / - mice were treated with $\mathrm{HU}$ for 3 consecutive days. Bone marrow was harvested from femurs and tibias $24 \mathrm{~h}$ after the third injection. Cells were stained with surface markers as in Figure 1 and apoptotic cells were detected by Annexin V-FITC. Annexin V-positive cells in various cell populations were analyzed by flow cytometry and representative flow plots were shown. (b) Quantitative analysis of Annexin V-positive cells in LSK and MPC cell populations. (c) Bid + I + and Bid - / - mice were treated with HU for 3 consecutive days. Twenty-three hours after the third $\mathrm{HU}$ injection, mice were treated with $100 \mu 10 \mathrm{mg} / \mathrm{ml} \mathrm{BrdU}$ for $1 \mathrm{~h}$ by intraperitoneal injection. Bone marrow cells were stained with surface markers as in Figure 1. After fixation and permeabilization, cells were treated with DNase for $1 \mathrm{~h}$ at $37^{\circ} \mathrm{C}$ and stained with anti-BrdU antibody for 20 min at room temperature. The incorporation of BrdU in various populations was analyzed by flow cytometry and representative flow plots were shown. (d) Quantitative analysis of the percentage of BrdU-positive cells in LSK and MPC populations. (e) HU-stressed Bid - I - bone marrow forms large GEMM colonies in methylcellulose culture. Bid + / + and Bid - / mice were treated with $\mathrm{HU}$ for 3 consecutive days and bone marrow was harvested from femurs and tibias $24 \mathrm{~h}$ after the third injection. Bone marrow cells were cultured in methylcellulose and representative GEMM colonies were shown on day 4 after plating. (f) Greater than five representative GEMM colonies observed in the first methylcellulose plating were photographed and the colony diameter was measured. Three independent experiments were performed with $n=5$ in each set. (g) GEMM colony number was counted in the first methylcellulose plating. (h) Quantitative analysis of GM, G colony and M colony, and total colony number observed in the first methylcellulose plating. ${ }^{\star} P<0.05,{ }^{\star \star} P<0.01$ (Statistical analysis was performed by a two-sample Student's $t$-test). Error bar, S.E.M. (b and $\left.\mathbf{d}\right)$, S.D. (f-h) 
a

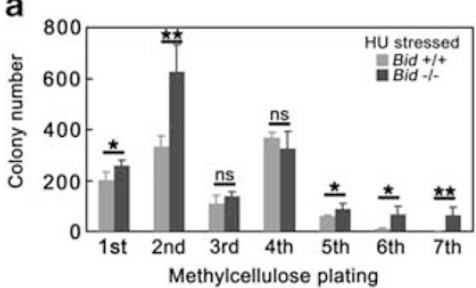

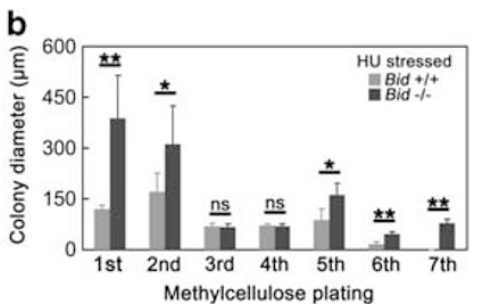
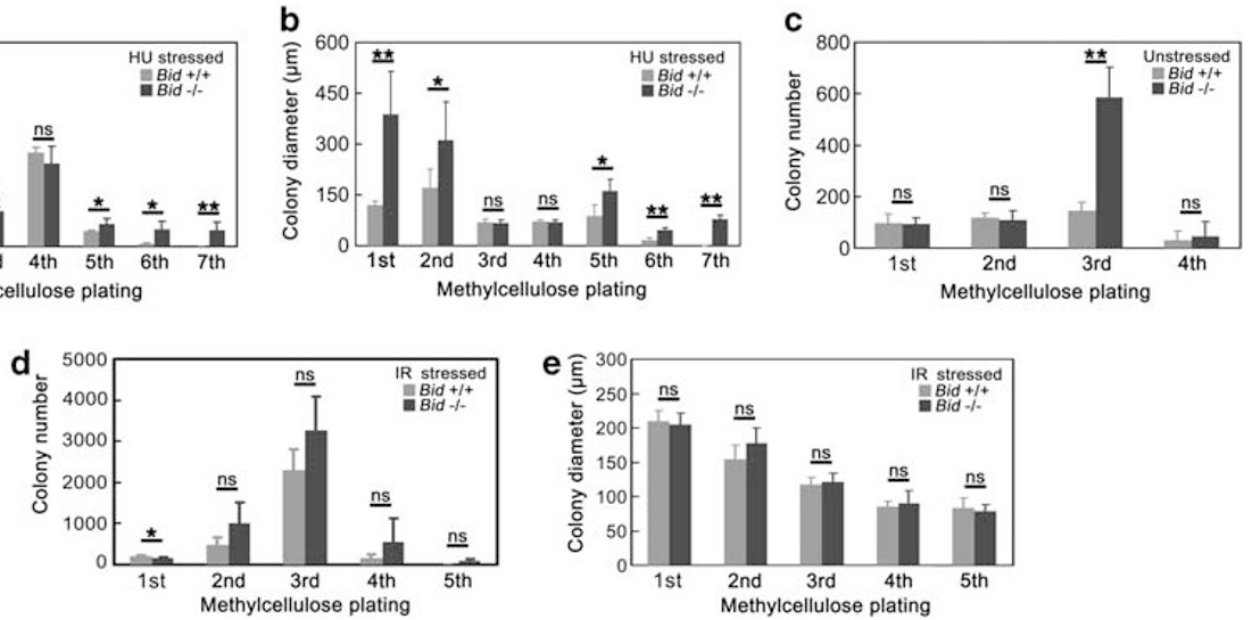

Figure $3 \mathrm{HU}$-stressed Bid - / - bone marrow increases colony formation capacity in methylcellulose re-plate culture. (a) Bid $+/+$ and Bid - I - mice were treated with $\mathrm{HU}$ for 3 consecutive days and bone marrow was harvested from femurs and tibias $24 \mathrm{~h}$ after the third injection. Bone marrow cells were cultured in methylcellulose culture. Quantitative analysis of the total colony number upon methylcellulose re-plating. Three independent experiments were performed with $n=5$ in each set. (b) Great than five representative GEMM and GM colonies in each plate were photographed in the first methylcellulose plating and in the re-plating process, respectively. The colony diameter was measured. Three independent experiments were performed with $n=5$ in each set. (c) Unstressed Bid $+I+$ and Bid $-I-$ mice were killed and bone marrow cells were cultured in methylcellulose culture. Total colonies number was counted. $n=5$ independent experiments. (d) Bid - / - bone marrow exhibits similar colony formation ability in methylcellulose culture following IR treatment. IR-stressed Bid - / - bone marrow forms normal GEMM colonies in methylcellulose culture. Bid + I+ and Bid - / - mice were irradiated with $2 \mathrm{~Gy}$ using a ${ }^{137} \mathrm{Cs}$ source. Mice were killed and bone marrow was harvested $24 \mathrm{~h}$ after irradiation. Bone marrow cells were cultured in methylcellulose. Two independent experiments were performed with $n=5$ in each set. Quantitative analysis of total colony number upon methylcellulose re-plating following IR treatment. (e) Great than five representative GEMM and GM colonies in each plate were photographed in the first methylcellulose plating and in the re-plating process, respectively. The colony diameter was measured. Two independent experiments were performed with $n=5$ in each set. ${ }^{\star} P<0.05$; ${ }^{\star \star} P<0.01$ (Statistical analysis was performed by a two-sample Student's t-test). Error bar, S.D.

while apparent after $1 \mathrm{~Gy} I \mathrm{R}$, increases after $2 \mathrm{~Gy}$ and increases again after $4 \mathrm{~Gy} .{ }^{6}$ To determine if the increased replating capacity of $\mathrm{Bid}-/$ - bone marrow was specific to treatment with $\mathrm{HU}, \mathrm{Bid}+/+$ and $\mathrm{Bid}-/-$ mice were irradiated with low dose IR (2Gy), chosen for a similar decrease in overall bone marrow cellularity in $\mathrm{Bid}+/+$ mice as observed with $\mathrm{HU}$. $^{19}$ Bone marrow from 2 Gy IR-stressed $\mathrm{Bid}+/+$ and Bid $-/-$ mice was harvested and cultured in methylcellulose. Both $\mathrm{Bid}+/+$ and $\mathrm{Bid}-/-$ bone marrow demonstrate modestly increased replating ability following $2 \mathrm{~Gy}$ relative to unstressed bone marrow. Distinct from HU-stress, IR-stressed Bid-/ - and Bid + /+ bone marrow showed similar colony formation ability in replating and similar GEMM colony size in the first culture (Figures $3 d$ and e). We further evaluated the effect of $4 \mathrm{~Gy}$ IR on replating capacity of $\mathrm{Bid}+/+$ and Bid-/- bone marrow. Bid + / + and Bid - / mice were irradiated with $4 \mathrm{~Gy}$ IR. At this dose, we observed no difference in methylcellulose colony formation between $\mathrm{Bid}+/+$ and Bid - / - bone marrow with no GEMM colonies noted in cultures from either genotype (data not shown). Furthermore, no colonies were obtained on the second replating. Thus, the phenotype in IR-stressed Bid-I - bone marrow differs from that observed following long-term replicative stress, consistent with our previous finding of a prominent role for Bid in the Atr-directed DDR. ${ }^{19}$

We have previously demonstrated that Bid-/- cells display limited Atr function and increased sensitivity to replicative stress. ${ }^{19,26}$ Furthermore, bone marrow of Bid-/- mice displays increased sensitivity to intraperitoneal injection of $\mathrm{HU}$ but not to $\mathrm{IR},{ }^{19}$ and $\mathrm{Bid}-/-$ but not Bid $+/+$ MPCs and LSK cells demonstrate increased
Annexin $\mathrm{V}^{+}$cells following $\mathrm{HU}$ (Figures $2 \mathrm{a}$ and $\mathrm{b}$ ). In addition, Bid - / - but not Bid+/+ LSK cells demonstrate increased BrdU incorporation following $\mathrm{HU}$ (Figures $2 \mathrm{c}$ and $\mathrm{d}$ ). Although we cannot exclude a contribution of protection from apoptosis due to loss of Bid in this ex vivo culture system, a rapid proliferation rate in addition to protection from apoptosis is necessary to account for the observed size of the colonies, arising from a single cell. Thus, we favor a model in which the formation of large GEMM colonies in Bid - / - methylcellulose cultures is predominantly due to increased proliferation of MPCs and LSK cells.

Bid-I- MPC and LSK populations are decreased relative to $\mathrm{Bid}+I+$ populations following 6 months of HU treatment. Enforced mobilization of HSCs from quiescence to a cycling state depletes stem cell self-renewal function. ${ }^{3}$ To determine whether long-term $\mathrm{HU}$ treatment results in the depletion of bone marrow function in Bid-Imice, Bid $+/+$ and $B i d-I-$ mice were treated with $\mathrm{HU}$ by intraperitoneal injection for 3 days, and allowed to recover for 7 days. This regimen was repeated for 6 months (see Materials and methods for details). ${ }^{27}$

Both $\mathrm{Bid}+\mathrm{I}+$ and $\mathrm{Bid}-/-$ mice survived 6 months of HU treatment, although a gradual loss of body weight (Supplementary Figure S1a) was observed in Bid - / - mice. After 6 months, MPC and LSK cell populations were increased relative to untreated mice for both $\mathrm{Bid}+/+$ and $\mathrm{Bid}-/-$ mice (Figures $5 \mathrm{a}-\mathrm{c}$ ). This expansion of LSK and MPC cell populations is also noted in unstressed aged mice, and may reflect compensation for decreased bone marrow function. ${ }^{17,18}$ Following long-term replicative stress induced 


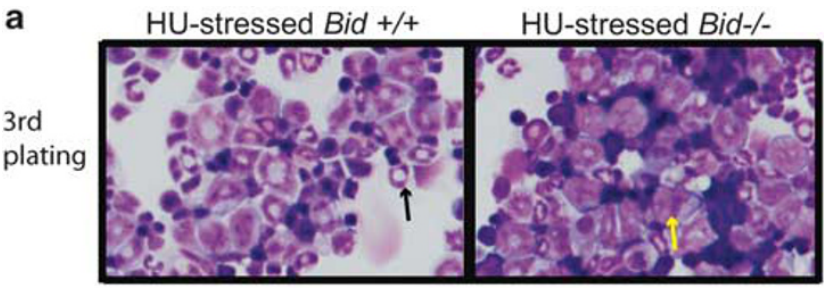

b

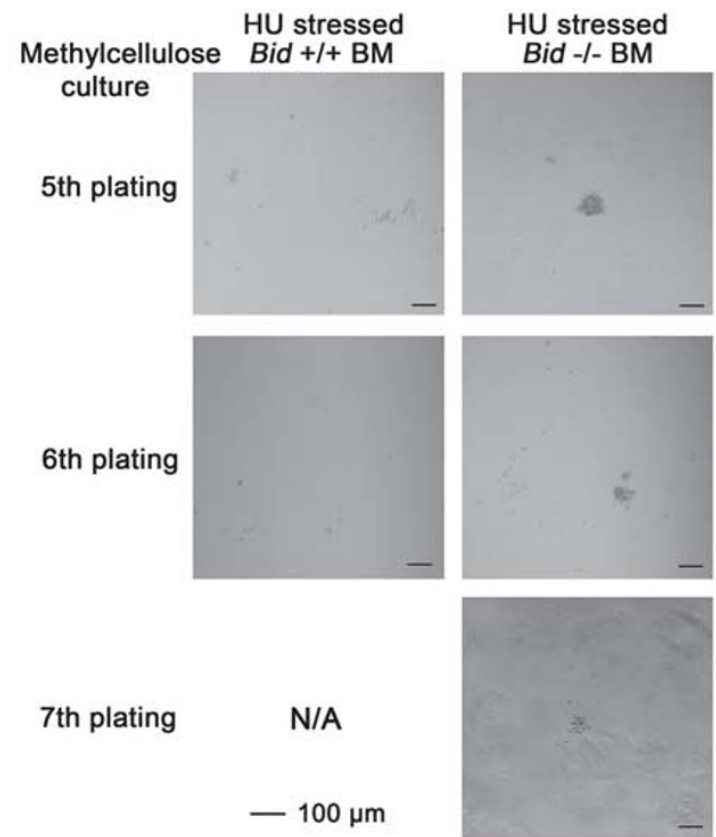

Figure 4 The immature differentiation state of HU-stressed Bid - / - but not $\mathrm{Bid}+1+$ bone marrow is maintained in vitro. (a) Bid $+1+$ and Bid $-I-$ mice were treated with $\mathrm{HU}$ for 3 consecutive days and bone marrow was harvested from femurs and tibias $24 \mathrm{~h}$ after the third injection. Bone marrow cells were cultured in methylcellulose. After the third plating, cells from the culture were harvested, washed in PBS, and stained by HEMA3 solution (Thermo Fisher Scientific, Pittsburgh, PA, USA) after cytospin. The black arrow denotes a mature neutrophil. The yellow arrow denotes an immature myeloid progenitor cell (myelocyte). (b) Bid $+/+$ and Bid $-/$ - mice were treated with $\mathrm{HU}$ for 3 consecutive days and bone marrow was harvested from femurs and tibias $24 \mathrm{~h}$ after the third injection. Bone marrow cells were cultured in methylcellulose and representative colonies are shown after the 5th-7th re-plating

by 6 months of $\mathrm{HU}$ treatment, $\mathrm{Bid}-/-$ bone marrow demonstrates a relative decrease in both MPC (specifically GMP) and LSK cell populations compared with $\mathrm{Bid}+/+$ bone marrow (Figures $5 a-d$ ). This relative depletion of LSK and progenitor cells is consistent with an inability of $\mathrm{Bid}-/$ - bone marrow progenitor cells to maintain homeostasis in conditions of long-term replicative stress.

Bid - I- bone marrow exhibits increased $\gamma \mathrm{H} 2 \mathrm{~A} . X$ staining following 6 months of $\mathrm{HU}$ treatment. To determine the effect of long-term $\mathrm{HU}$ on bone marrow colony forming ability, bone marrow was harvested from $\mathrm{Bid}+/+$ and Bid $-/-$ mice treated for 6 months with $\mathrm{HU}$ as above, and cultured in methylcellulose. Similar GEMM colony number (Figure 6a) and size (not shown) were observed in Bid-I- and $\mathrm{Bid}+\mathrm{I}+$ cultures, suggesting that the augmented $\mathrm{HU}$ induced $\mathrm{Bid}-/-$ LSK mobilization is attenuated following long-term $\mathrm{HU}$ treatment. In addition, similar colony formation ability was observed between $\mathrm{Bid}+/+$ and Bid-I- in methylcellulose replating (Figure $6 b$ ). The increased sensitivity of $\mathrm{Bid}-/$ - bone marrow to $\mathrm{HU}$, while still evident, no longer reaches statistical significance after 6 months of $\mathrm{HU}$ treatment (Supplementary Figure S1b).

Replicative stress induces genomic instability and DNA damage at the cellular level. ${ }^{10} \gamma$ H2A.X is phosphorylated following DNA damage (Supplementary Figure S2). DNA damage levels were detected by $\gamma \mathrm{H} 2 \mathrm{~A}$.X staining following 6 months of $\mathrm{HU}$ treatment. The $\gamma \mathrm{H} 2 \mathrm{~A}$.X-positive cells measured by immunofluorescence were significantly increased in Bid-I- bone marrow (Figures $6 \mathrm{c}$ and $\mathrm{d}$ ), suggesting accumulation of DNA damage following long-term HU treatment. To further identify the cell populations harboring $\gamma \mathrm{H} 2 \mathrm{~A}$.X-positive cells, Bid $+/+$ and Bid $-/$ - bone marrow were stained with immunophenotypic surface markers and $\gamma \mathrm{H} 2 \mathrm{~A}$.X-positive cells were detected by flow cytometry. Interestingly, $\quad \gamma \mathrm{H} 2 \mathrm{~A}$.X-positive cells were significantly increased in Bid-I- MPCs but not the LSK cells (Figures $6 e-g$ ), suggesting that the accumulated $\gamma \mathrm{H} 2 \mathrm{~A}$.X-positive cells in Bid - / - bone marrow were predominantly progenitor cells. Different DNA repair mechanisms have been reported between HSCs and MPCs following DSBs. ${ }^{6}$ Our results are consistent with cycling HSCs and MPCs utilizing a different mechanism to repair DNA damage due to replicative stress. Alternatively, HSCs may preferentially differentiate upon accumulation of DNA damage.

Bone marrow function is diminished in Bid- $I$-bone marrow following 6 months of $\mathrm{HU}$ treatment. HSC mobilization is linked to stem cell functional depletion. ${ }^{5,32}$ We asked whether 6 months of $\mathrm{HU}$ treatment alters the competitive repopulating ability of $\mathrm{Bid}+/+$ and Bid-/bone marrow. Lineage-depleted Bid $+/+$ (CD45.2) and Bid - / - (CD45.2) bone marrow cells were transplanted into lethally irradiated congenic recipient mice (CD45.1) with equal amounts of lineage-depleted competitor bone marrow cells (CD45.1). The reconstitution of the hematopoietic system was detected by the CD45.2/CD45.1 ratio in peripheral blood from the recipient mice over time (Figure 7a). The percentage of CD45.2 + cells in Bid-/ peripheral blood was significantly diminished compared with $\mathrm{Bid}+/+$ peripheral blood, as demonstrated by the decreased CD45.2/CD45.1 ratio in the recipient mice for the Bid-I - but not the Bid $+/+$ test populations (Figures 7b and c). As a control, no defect in the reconstitution capacity was observed in untreated $\mathrm{Bid}-/-$ bone marrow in a competitive reconstitution assay, but rather a slight competitive advantage, ${ }^{20}$ suggesting that the diminished HSC function is due to long-term HU treatment. Distinct from the HSC exhaustion noted in other mouse models,,, 14 the reconstitution capacity of $\mathrm{Bid}-/-$ HSCs is only impaired following long-term HU treatment. Consistent with this thesis, Bid-1- MPCs but not HSCs display increased cell death following $\mathrm{HU}$, suggesting that the increased death of Bid - / - MPCs triggers mobilization of Bid $+/+$ HSCs.

To more stringently evaluate the regenerative capacity of wild type and Bid - I - bone marrow following 6 months of $\mathrm{HU}$ treatment, we performed a secondary transplant. Mice from 

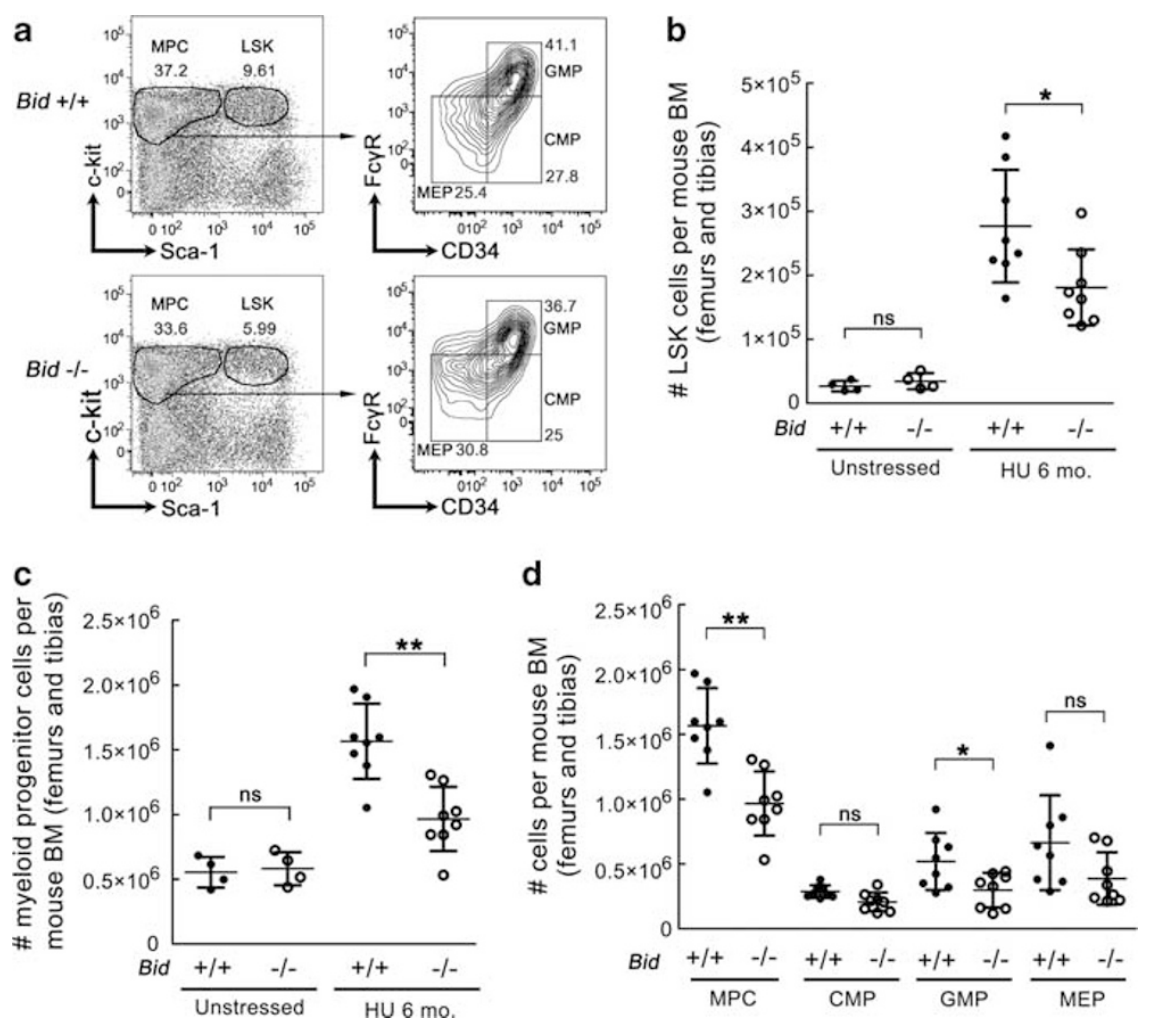

Figure 5 Bid - / - MPC and LSK cell populations are diminished following long-term HU treatment. (a) Bid + / + and Bid - / - mice were continuously treated with HU for 6 months and bone marrow was harvested from femurs and tibias $24 \mathrm{~h}$ after the last HU injection. Cells were first stained with lineage markers (biotinylated CD3, B220, Gr-1 and Ter119) and then stained with c-kit, Sca1, CD34, and FcyRII/III. MPC and LSK cells were defined as in Figure 1. GMP, CMP, and MEP cells were defined as in Figure 1. Representative flow plots were shown. (b) Quantitative analysis of LSK population cell number. (c) Quantitative analysis of MPC population cell number. (d) Quantitative analysis of CMP, GMP and MEP population cell number. ${ }^{*} P<0.05,{ }^{\star \star} P<0.01$ (Statistical analysis was performed by a two-sample Student's $t$-test). Error bar, S.E.M.

the primary competitive repopulation experiment were killed at 6 months. In all, $1 \times 10^{5}$ CD45. $2+$ whole-bone marrow cells were injected with $1 \times 10^{5}$ congenic CD45.1 + competitor cells into lethally irradiated CD45.1 + mice. Of note, the cells were not sorted to obtain purified populations to avoid confounding effects on viability of Bid-I- versus Bid $+/+$ cells in the low serum, high-pressure conditions of the flow sorting procedure. Peripheral blood was analyzed 2 months following transplant for the percentage of CD45.2 + cells. Bid - I - bone marrow cells demonstrate decreased repopulating ability in secondary transplantation experiments (Figure 7d), further demonstrating that Bid has a role in maintaining bone marrow function following long-term replicative stress.

\section{Discussion}

HSCs are susceptible to genotoxic stress from multiple etiologies. Recently, the response of HSCs and MPCs to IR has been studied in vivo, in mice and humans. Bid has been shown to mediate the Atr-directed response to replicative stress, but the physiological consequence of long-term replicative stress on bone marrow function and Bid's role in this regulation have not been determined. In this study, we use Bid-/- mice to investigate how defects in this BH3-only family member impact hematopoietic function following replicative stress. Our results are most consistent with a survival role for Bid following replicative stress. Bid-/MPCs display increased sensitivity to replicative stress, resulting in a compensatory increase in cycling LSK cells. The increased cycling of LSK cells in Bid-/- mice leads to exhaustion, resulting in a diminished LSK and MPC populations (Figure 7d).

Atr has important roles in maintenance of genomic integrity in proliferating cells, as well as in normal DNA replication. ${ }^{10}$ Germ line deletion of Atr results in early embryonic lethality. ${ }^{33}$ Atr-deficient mice showed defects in tissue homeostasis with aging-related phenotypes and exhaustion of tissue-specific stem and progenitor cells. ${ }^{14,32,34}$ The contribution of Atr's functions in replication versus the DDR to these stem and progenitor cell defects has not been determined. Cells harboring mutated RPA $70^{35}$ or the Atr binding partner Atrip ${ }^{36}$ showed a normal cell cycle profile, but impaired DDR. Similarly, Bid-I- cells demonstrated a normal cell cycle profile, but impaired Atr function following replicative stress. ${ }^{19,26}$ In this study, 6 months HU-treated Bid - /- mice demonstrate decreased LSK and MPCs relative to Bid $+/+$ mice. Interestingly, 1-year-aged untreated Bid-/- mice show a similar percentage of LSKs and MPCs as Bid $+1+$ mice (Supplementary Figure S3). ${ }^{20}$ These results are consistent with our previous finding that the major function of Bid in the Atr response is DNA damage-induced. ${ }^{19}$ 

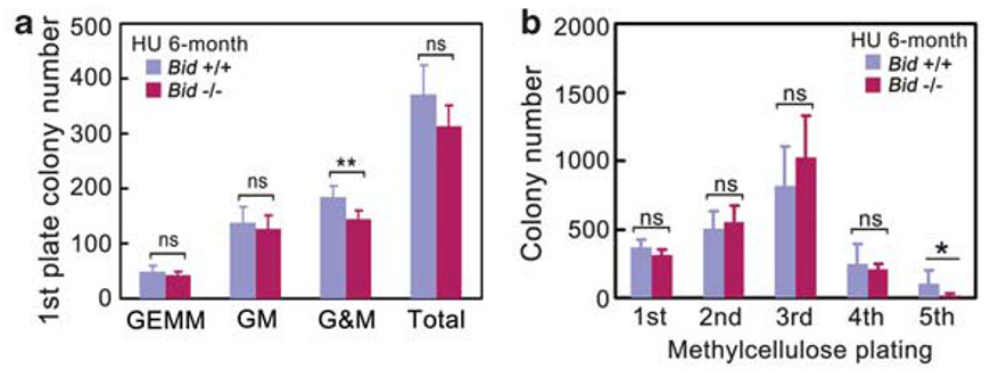
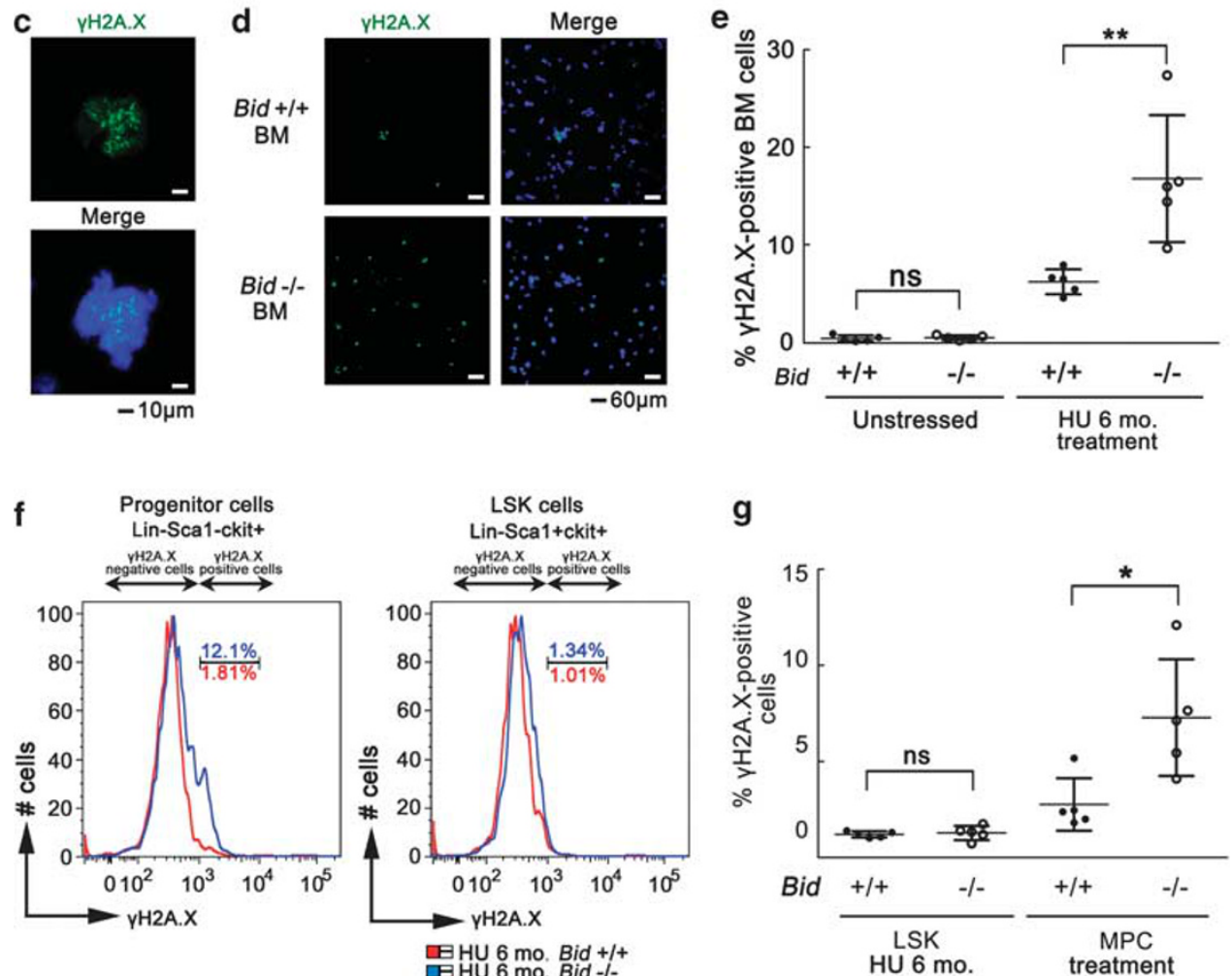

Figure 6 Bid $-/$ - bone marrow exhibit increased $\gamma$ H2A.X staining following 6 months of $\mathrm{HU}$ treatment. (a) Bid - / - bone marrow exhibits similar colony formation ability as Bid $+/+$ in methylcellulose culture. Bid $+/+$ and Bid $-/$ - mice were treated with $\mathrm{HU}$ for 6 months and bone marrow was harvested from femurs and tibias $24 \mathrm{~h}$ after the last $\mathrm{HU}$ injection. Bone marrow cells were cultured in methylcellulose and colonies were counted on day 7 after plating. Two independent experiments were performed with $n=5$ in each set. (b) Quantitative analysis of total colony number upon methylcellulose re-plating. (c and d) Bid - / - bone marrow exhibit increased $\gamma \mathrm{H} 2 \mathrm{~A}$.X staining following 6 months of $\mathrm{HU}$ treatment. Bid $+I+$ and Bid $-I$ - mice were treated with $\mathrm{HU}$ for 6 months and bone marrow was harvested from femurs and tibias $24 \mathrm{~h}$ after the last $\mathrm{HU}$ injection. Bone marrow cells were fixed, permeabilized and stained by Alexa Fluor 488-conjugated anti-phospho-Histone H2A.X (Ser139). Typical $\gamma \mathrm{H} 2 \mathrm{~A} . \mathrm{X}$ foci were observed in Bid - I - bone marrow (c, high resolution image). Representative figures of $\gamma \mathrm{H} 2 \mathrm{~A}$.X staining in around 100 bone marrow cells were shown in (d). DNA was detected by Hoechst stain (blue). (e) Quantitative analysis of $\gamma$ H2A.X-positive bone marrow cells. 150-300 cells/mice were calculated for five mice. (f) Bid - / - MPC but not HSC populations exhibit increased $\gamma \mathrm{H} 2 \mathrm{~A}$.X staining following 6 months $\mathrm{HU}$ treatment. Bid $+/+$ and Bid $-I-$ mice were treated with HU for 6 months and bone marrow was harvested. Cells were first stained with cell surface markers as in Figure 1. Then, cells were fixed and permeabilized and stained with anti-phospho-Histone H2A.X (Ser139) for $30 \mathrm{~min}$ at room temperature and $\gamma \mathrm{H} 2 \mathrm{~A}$.X-positive cells was detected by flow cytometry. $\gamma \mathrm{H} 2 \mathrm{~A}$.X-positive cells were defined as Alexa Fluor 488 intensity $>10^{3}$ (See explanation in Supplementary Figure S2b). Representative flow plots were shown. (g) Quantitative analysis of the percentage of $\gamma$ H2A.X-positive cells in MPC and LSK populations from five mice. ${ }^{\star} P<0.05,{ }^{\star *} P<0.01$ (Statistical analysis was performed by a two-sample Student's $t$-test). Error bar, (a and $\left.\mathbf{b}\right)$ S.D.; (e and $\left.\mathbf{g}\right) S . E . M$.

Bid has been demonstrated to have dual roles in both programmed cell death and the ${ }^{26,37}$ DDR. Distinct functional domains mediate the two functions of Bid. ${ }^{26}$ The apoptotic function of Bid is predominantly mediated by its caspasecleavage sites $^{21,22}$ and $\mathrm{BH} 3$ domain, ${ }^{38}$ while Bid executes its function in the DNA damage signaling pathways by its Atm/Atr phosphorylation sites ${ }^{26,37}$ its unique Helix 4 and RPA-interacting domains. ${ }^{19,39}$ Bid-/ - mice spontaneously develop chronic myelomonocytic leukemia (CMML) and the tumor cells display chromosomal aberrations. ${ }^{20}$ It is likely that both the apoptotic and DNA damage function of Bid work synergistically to maintain hematopoiesis. As both cell death and DNA damage signaling pathways are important for tissue homeostasis and genomic integrity, it will be interesting to determine which function of Bid directs the tumor suppressor function of Bid in vivo. 


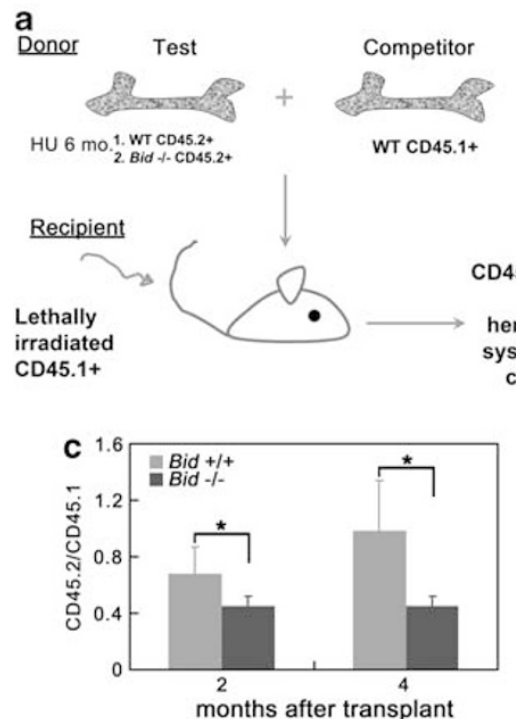

b

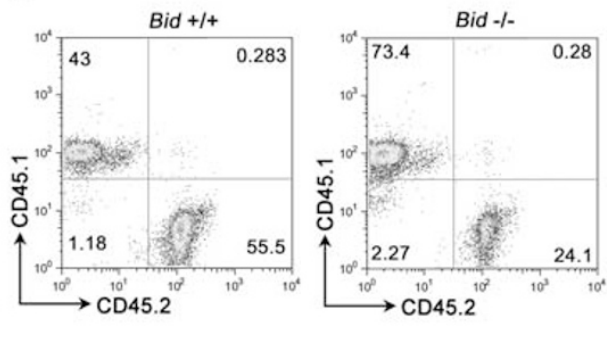
system by flow cytometry

months after transplant
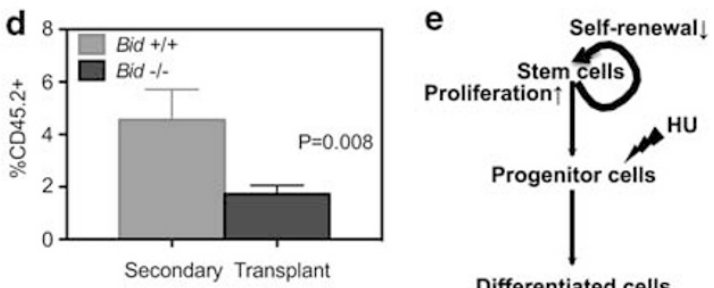

Figure 7 Bone marrow repopulation ability is diminished in Bid - / - bone marrow following 6 months of HU treatment. (a) Experimental design. Following 6 months of $\mathrm{HU}$ treatment, Bid $+/+$ and Bid - I - mice (CD45.2) were killed and bone marrow were obtained from femurs and tibias. In all, $1 \times 10^{5}$ lineage- bone marrow cells from either Bid + I + or Bid $-I$ - mice $(C D 45.2+)$ following HU treatment together with $1 \times 10^{5}$ lineage- bone marrow 'Competitor' cells $(C D 45.1+)$ were transplanted into lethally irradiated recipients (CD45.1 +) by retro orbital injection. Hematopoietic reconstitution was evaluated by flow cytometry of peripheral blood at 2 and 4 months after the transplant. (b) Peripheral blood was obtained from the recipient mice transplanted from Bid + I + or Bid - I - mice following 6 months of HU treatment. Following red blood cell lysis, blood cells were stained with anti-CD45.1 and anti-CD45.2 antibodies, and analyzed in flow cytometry. Representative flow plots were shown. (c) Quantitative analysis of the ratio of CD45.2-positive cells versus CD45.1-positive cells in the peripheral blood of recipient mice 4 months after transplant. ${ }^{*} P<0.05 ; n=10$. (Statistical analysis was performed by a two-sample Student's t-test). Error bar, S.D. (d) Quantitative analysis of the percentage of CD45.2-positive cells in the peripheral blood of recipient mice 2 months after secondary transplant. ${ }^{*} P=0.008 ; n=15$. (Statistical analysis was performed by a two-sample Student's t-test). Error bar, S.D. (e) Proposed model of Bid's function in the hematopoietic system following replicative stress. In Bid $+I+$ mice, Bid facilitates normal ATR function to maintain replication fork and genomic integrity in the cycling progenitor cells following replicative stress. In Bid - / - mice, Bid - / - MPCs are hypersensitive to replicative stress. The excessive depletion of MPCs results in a compensatory increase in mobilization of hematopoietic stem cells. Long-term HU treatment causes increased proliferation of LSK cells and depletion of bone marrow repopulation function in Bid - / - mice

$\mathrm{HU}$ is a ribonucleotide reductase inhibitor and therefore has the potential to affect cycling cells. The major effects seen are hematopoietic, and this is the indication for usage in the clinic. We did not see any evidence of other HU toxicities, such as GI toxicity in the Bid - / - or Bid+ / + mice during long-term HU treatment, although subclinical Gl irritation might contribute to the weight loss. Alternatively, the accumulation of increased genomic damage in $\mathrm{Bid}-/-$ mice might lead to premature aging manifest by decreased muscle mass and subcutaneous fat. Importantly, the hematopoietic changes that we report in $\mathrm{Bid}-/-$ mice treated with $\mathrm{HU}$ are manifest in competitive transplant experiments and thus cannot be attributed to altered nutritional status.

We speculate that the increased DNA damage observed in MPCs over LSK cells is due to the fact that MPCs cycle rapidly, whereas LSK cells are generally more slowly cycling. This is the simplest explanation for the differential effects observed in MPC and LSK cells, and is consistent with the known effects of $\mathrm{HU}$ to induce replicative stress in cycling cells, and the known role for Bid in the DDR to replicative stress.

We have previously reported that $50 \%$ of $\mathrm{Bid}-/-$ mice spontaneously develop CMML in 20 months. Ninety-five percentage of $\mathrm{Bid}-\mathrm{I}-$ mice are normal at 1 year of age. ${ }^{20}$ Furthermore, the tumors are characterized by translocations and trisomy, lesions that occur because of chromatid type errors in DNA repair. The development of CMML might result from DNA damage that accumulates after 1 year of age.
Alternatively, the tumors may be precipitated by genomic damage that is not evident by gamma H2AX.

In our previous study, ${ }^{20}$ we noted an increase in clonogenic potential of $\mathrm{Bid}-/-$ bone marrow on the first plating in methylcellulose cultures that also included GMCSF and GCSF, growth factors that affect differentiated myeloid cells. Loss of Bid may potentiate the proliferative response of mature myeloid cells to these growth factors, resulting in increased colonies. Indeed, hyper-responsiveness to GCSF is characteristic of the abnormal cells in Juvenile myelomonocytic leukemia a disorder that closely resembles CMML and the phenotype observed in aging Bid - / - mice. Experiments to determine if $\mathrm{Bid}-\mathrm{I}-$ bone marrow is hyper-responsive to GMCSF and GCSF are in progress in the lab. In the current study, we did not include GMCSF or GCSF, and observe differences in later replatings.

First identified at the $t(14 ; 18)$ of follicular lymphoma, Bcl-2 and its family have been demonstrated to have crucial roles in maintenance of hematopoiesis. ${ }^{40}$ Besides sensing and transducing various survival or death signals to mitochondria to regulate apoptosis, more and more 'non-canonical' functions of $\mathrm{Bcl}-2$ family members have been identified. ${ }^{41} \mathrm{We}$ have demonstrated that Bid, a $\mathrm{BH} 3-o n l y ~ B c l-2$ family member regulates the response of LSK cells and early progenitor cells to replicative stress. Investigating the physiological function of these novel properties of $\mathrm{Bcl}-2$ members will deepen our understanding of $\mathrm{Bcl}-2$ family in the hematopoietic system. 


\section{Materials and Methods}

Mice and DNA damage treatments. For $\mathrm{HU}$ treatment, wild type and Biddeficient C57/BL6 mice (6-8 weeks old) were treated with $100 \mathrm{mg} / \mathrm{kg} /$ day HU by intraperitoneal injection for 3 consecutive days. Mice were killed and bone marrow was harvested from femurs and tibias $24 \mathrm{~h}$ after the third injection. For long-term $\mathrm{HU}$ treatment, after 3-consecutive-day-HU treatment, mice were released from $\mathrm{HU}$ treatment for 7 days and subjected to $\mathrm{HU}$ treatment again for 3 consecutive days. This treatment cycle was repeated for 6 months. For IR treatment, wild type and Bid - I - C57/BL6 mice (6-8 weeks old) were irradiated with 2 Gy using a ${ }^{137} \mathrm{Cs}$ source. Mice were killed and bone marrow was harvested $24 \mathrm{~h}$ after irradiation. At least two independent experiments were performed with $n=5$ in each set (See figure legend for details).

Cell staining and flow cytometry. Bone marrow cells were stained with the following antibody in staining buffer (3\% FBS in phosphate-buffered saline (PBS)): biotinylated CD3 (BD Biosciences, San Diego, CA, USA), biotinylated B220 (BD Biosciences), biotinylated TER119 (BD Biosciences), biotinylated Gr-1 (BD Biosciences), APC-conjugated anti-c-kit (BD Biosciences), PE-Cy7conjugated anti-Sca1 (ebiosciences, San Diego, CA, USA), FITC-conjugated anti-CD34 (BD Biosciences), FITC-conjugated anti-BrdU (BD Biosciences), PE-conjugated anti-Fc $\gamma R$ III/III (eBioscience), Pacific blue-conjugated streptavidin (Life Technologies, Grand Island, NY, USA), Alexa Fluor 488-conjugated antiphospho-Histone H2A.X (Ser139) (EMD Millipore, Billerica, MA, USA, \#9719), PE-conjugated anti-CD45.1 (BD Biosciences), and FITC-conjugated anti-CD45.2 (BD Biosciences). For lineage staining, cells were stained with biotinylated CD3, biotinylated B220, biotinylated Ter119 and biotinylated Gr-1 first for 20 min on ice. Then, cells were stained with Pacific blue-conjugated streptavidin, APCconjugated anti-c-kit, PE-Cy7-conjugated anti-Sca1, FITC-conjugated anti-CD34 and PE-conjugated anti-FcyRII/III for $20 \mathrm{~min}$ on ice. Cell population data were obtained by a five-laser BD LSRII (Vanderbilt Flow Cytometry Core, Nashville, TN, USA) and analyzed by Flowjo 8. Compensation parameter setting was performed using BD CompBead (BD Biosciences).

BrdU incorporation and cell death analysis. BrdU incorporation analysis was performed according to BrdU Flow Kits (BD Biosciences). Briefly, mice were treated with $100 \mu \mathrm{l} 10 \mathrm{mg} / \mathrm{ml} \mathrm{BrdU}$ solution by intraperitoneal injection. Incorporation of BrdU was detected in bone marrow from femurs and tibias $1 \mathrm{~h}$ post injection. Erythrocytes were lysed in RBC lysis buffer $(10 \mathrm{mM}$ Tris- $\mathrm{HCl}$, $0.83 \% \mathrm{NH}_{4} \mathrm{Cl}, \mathrm{pH} 7.3$ ) and bone marrow cells were stained with various surface markers as mentioned in the figure legends. Then, cells were fixed and permeabilized with BD Cytofix (BD Biosciences)/Cytoperm Buffer (BD Biosciences), and incubated with BD Cytoperm Plus Buffer (BD Biosciences) followed by an additional short fixation with BD Cytofix/Cytoperm Buffer (BD Biosciences). The incorporated BrdU was exposed by treatment with $30 \mu \mathrm{g}$ DNase for $1 \mathrm{~h}$ at $37^{\circ} \mathrm{C}$ and probed with FITC-conjugated anti-BrdU antibody (eBioscience) for $20 \mathrm{~min}$ at room temperature. Cell death analysis was performed according to Annexin V-FITC Apoptosis Detection Kit (BioVision, Milpitas, CA, USA). Briefly, bone marrow cells were obtained from femurs and tibias, and erythrocytes were lysed in RBC lysis buffer ( $10 \mathrm{mM}$ Tris- $\mathrm{HCl}, 0.83 \% \mathrm{NH}_{4} \mathrm{Cl}, \mathrm{pH} 7.3$ ). Cells were stained with various surface markers as mentioned in the figure legends. Then, cells were stained with Annexin V-FITC in binding buffer (10 mM HEPES/NaOH, $150 \mathrm{mM} \mathrm{NaCl}, 5 \mathrm{mM} \mathrm{KCl}, 1 \mathrm{mM} \mathrm{MgCl}_{2}, 2 \mathrm{mM} \mathrm{CaCl}_{2}, \mathrm{pH} 7.4$ ) at room temperature for $15 \mathrm{~min}$.

Methylcellulose culture. Methylcellulose culture was performed as previously described. ${ }^{20}$ Briefly, bone marrow was harvested from femurs and tibias, and erythrocytes were lysed in RBC lysis buffer. Then, $5 \times 10^{4}$ bone marrow cells were resuspended in Methylcult H4100 (StemCell Technologies, VanCouver, BC, Canada) supplemented with bovine serum albumin (BSA), FBS, Insulin and Transferrin, with the following cytokines: SCF, IL3, IL6, and EPO. Cells were plated in $35-\mathrm{mm}$ dishes and incubated in a humidified atmosphere at $37^{\circ} \mathrm{C}, 5 \% \mathrm{CO}_{2}$. Typical colonies were photographed using a Leica DM IRBE inverted wild field microscope (Vanderbilt Cell Imaging Shared Resource). After 6 days, the cultures were washed with PBS, counted, and replated at the same density. The captured image was analyzed by Photoshop CS3 to measure the diameter of the compact center of each GEMM or GM colony.

$\gamma$ H2A.X immunofluorescence and intra-cellular staining. Bone marrow was harvested from femurs and tibias, and erythrocytes were lysed in
RBC lysis buffer. Then, $5-10 \times 10^{4}$ bone marrow cells were centrifuged onto a glass coverslip by cytospin. Then, cells were fixed in $3 \%$ paraformaldehyde/ $2 \%$ sucrose and permeabilized by Triton X-100 solution (0.5\% Triton X-100, $20 \mathrm{mM}$ HEPES pH 7.4, $50 \mathrm{mM} \mathrm{NaCl}, 3 \mathrm{mM} \mathrm{MgCl}, 300 \mathrm{mM}$ sucrose). $\gamma$ H2A.X-positive cells were detected by immunofluorescence using Alexa Fluor 488-conjugated anti-phospho-Histone H2A.X (Ser139) (EMD Millipore, \#9719). The cells were examined using a Leica DM IRBE inverted wild field microscope (Vanderbilt Cell Imaging Shared Resource). For $\gamma \mathrm{H} 2 \mathrm{~A}$.X flow cytometry analysis, bone marrows were obtained from femurs and tibias, and erythrocytes were lysed in RBC lysis buffer. Bone marrow cells were stained with various surface markers as mentioned in the figure legends. Then, cells were fixed and permeabilized with BD Cytofix/Cytoperm Buffer, and incubated with $\mathrm{BD}$ Cytoperm Plus Buffer followed by an additional short fixation with BD Cytofix/ Cytoperm Buffer. Then, cells were stained with Alexa Fluor 488-conjugated anti-phospho-Histone H2A.X (Ser139) (EMD Millipore) for $30 \mathrm{~min}$ at room temperature and $\gamma \mathrm{H} 2 \mathrm{~A}$.X-positive cells were detected by flow cytometry.

Competitive repopulation/bone marrow transplantation. C57/BL6 mice recipient mice (CD45.1) were lethally irradiated with nine Gy using a ${ }^{137} \mathrm{Cs}$ source. Donor cells were obtained from Bid $+/+$ (CD45.2) and Bid - / - (CD45.2) mice following 6 months HU treatment. Bone marrows were obtained from femurs and tibias, and erythrocytes were lysed in RBC lysis buffer. Then, cells were stained with lineage markers (CD3, B220, TER119 and Gr-1) for $20 \mathrm{~min}$ on ice. Lineage ${ }^{+}$cells were depleted by Dynabeads Sheep anti-Rat IgG (Life Technologies) and lineage-cells were counted. In all, $1 \times 10^{6}$ lineage-bone marrow cells from either Bid $+/+$ or Bid $-/-$ C57/BL6 mice (CD45.2) following 6-months $\mathrm{HU}$ treatment together with $1 \times 10^{6}$ lineage-bone marrow cells from wild type C57/BL6 mice (CD45.1+) were equally transplanted into 10 lethally irradiated recipients $(C D 45.1+)$ by intravenous injection. Hematopoietic reconstitution was detected followed two and four months after the transplant. Peripheral blood from the recipient mice was subjected to Lymphocyte Separation Medium (MP Biomedicals, Solon, OH, USA) and lymphocytes were collected after centrifugation at 3000 r.p.m. for $30 \mathrm{~min}$. The lymphocytes were washed once with PBS, stained by anti-PE-CD45.1 and anti-FITC-CD45.2 antibodies, and CD11b, and analyzed by flow cytometry.

Secondary transplants: Mice from the primary competitive repopulation experiment were killed at 6 months. $1 \times 10^{5} \mathrm{CD} 45.2+$ whole-bone marrow cells were injected with $1 \times 10^{5}$ congenic CD45.1 + competitor cells into lethally irradiated CD45.1 + mice. Cells were not sorted to avoid confounding effects because of cellular stress induced by the sorting procedure. Cells were transplanted into lethally irradiated congenic CD45.1 + mice, and peripheral blood was analyzed as above.

Statistical analysis. Student's $t$-test was used for all statistical analysis (Excel 2002).

\section{Conflict of Interest}

The authors declare no conflict of interest.

Acknowledgements. We thank Drs Jennifer Pietenpol, Scott Hiebert, Elizabeth Yang, David Cortez, Laurie Lee, Kathy Gould, and Atan Gross for helpful discussions. This work was supported by funds from NIH R01 HL088347, a Gabrelle's Angel Foundation Scholar award, a Kimmel Scholar award, and ACS IRG58-009-47 to SSZ, and support for use of facilities from the Vanderbilt-Ingram Cancer Center (NIH 2P30CA068485). Cell imaging experiments were performed in the VUMC Cell Imaging Shared Resource (NIH grants CA68485, DK20593, DK58404, HD15052, DK59637 and EY08126). Dr Zinkel is funded by the NIH (R01 HL088347), the Kimmel Foundation, and Gabrielle's Angel Foundation. Dr Yang and Ms Aiello were funded by Dr Zinkel through the sources listed above.

1. Kondo M, Wagers AJ, Manz MG, Prohaska SS, Scherer DC, Beilhack GF et al. Biology of hematopoietic stem cells and progenitors: implications for clinical application. Annu Rev Immunol 2003; 21: 759-806.

2. Cairns J. Mutation selection and the natural history of cancer. Nature 1975; 255: 197-200

3. Zon LI. Intrinsic and extrinsic control of haematopoietic stem-cell self-renewal Nature 2008; 453: 306-313. 
4. Reya T, Morrison SJ, Clarke MF, Weissman IL. Stem cells, cancer, and cancer stem cells Nature 2001; 414: 105-111.

5. Cheng T, Rodrigues N, Shen H, Yang Y, Dombkowski D, Sykes M et al. Hematopoietic stem cell quiescence maintained by p21cip1/waf1. Science 2000; 287: 1804-1808.

6. Mohrin M, Bourke E, Alexander D, Warr MR, Barry-Holson K, Le Beau MM et al. Hematopoietic stem cell quiescence promotes error-prone DNA repair and mutagenesis. Cell Stem Cell 2010; 7: 174-185.

7. Milyavsky M, Gan OI, Trottier M, Komosa M, Tabach O, Notta F et al. A distinctive DNA damage response in human hematopoietic stem cells reveals an apoptosis-independent role for p53 in self-renewal. Cell Stem Cell 2010; 7: 186-197.

8. Sancar A, Lindsey-Boltz LA, Unsal-Kacmaz K, Linn S. Molecular mechanisms of mammalian DNA repair and the DNA damage checkpoints. Annu Rev Biochem 2004; 73: 39-85.

9. Zou L, Elledge SJ. Sensing DNA damage through ATRIP recognition of RPA-ssDNA complexes. Science 2003; 300: 1542-1548.

10. Cimprich KA, Cortez D. ATR: an essential regulator of genome integrity. Nat Rev Mol Cell Biol 2008; 9: 616-627.

11. Matsuoka S, Ballif BA, Smogorzewska A, McDonald 3rd ER, Hurov KE, Luo J et al. ATM and ATR substrate analysis reveals extensive protein networks responsive to DNA damage. Science 2007; 316: 1160-1166.

12. Mordes DA, Cortez D. Activation of ATR and related PIKKs. Cell Cycle 2008; 7: 2809-2812

13. Wright JA, Keegan KS, Herendeen DR, Bentley NJ, Carr AM, Hoekstra MF et al. Protein kinase mutants of human ATR increase sensitivity to UV and ionizing radiation and abrogate cell cycle checkpoint control. Proc Natl Acad Sci USA 1998; 95: 7445-7450.

14. Ruzankina Y, Pinzon-Guzman C, Asare A, Ong T, Pontano L, Cotsarelis G et al. Deletion of the developmentally essential gene ATR in adult mice leads to age-related phenotypes and stem cell loss. Cell Stem Cell 2007; 1: 113-126.

15. Ito K, Hirao A, Arai F, Matsuoka S, Takubo K, Hamaguchi I et al. Regulation of oxidative stress by ATM is required for self-renewal of haematopoietic stem cells. Nature 2004; 431 : 997-1002.

16. Dumble M, Moore L, Chambers SM, Geiger H, Van Zant G, Goodell MA et al. The impact of altered p53 dosage on hematopoietic stem cell dynamics during aging. Blood 2007; 109: 1736-1742.

17. Rossi DJ, Bryder D, Seita J, Nussenzweig A, Hoeijmakers J, Weissman IL. Deficiencies in DNA damage repair limit the function of haematopoietic stem cells with age. Nature 2007; 447: 725-729.

18. Nijnik A, Woodbine L, Marchetti C, Dawson S, Lambe T, Liu C et al. DNA repair is limiting for haematopoietic stem cells during ageing. Nature 2007; 447: 686-690.

19. Liu Y, Bertram CC, Shi Q, Zinkel SS. Proapoptotic Bid mediates the Atr-directed DNA damage response to replicative stress. Cell Death Differ 2011; 18: 841-852.

20. Zinkel SS, Ong CC, Ferguson DO, Iwasaki H, Akashi K, Bronson RT et al. Proapoptotic BID is required for myeloid homeostasis and tumor suppression. Genes Dev 2003; 17: 229-239.

21. Luo X, Budihardjo I, Zou H, Slaughter C, Wang X. Bid, a Bcl2 interacting protein, mediates cytochrome $c$ release from mitochondria in response to activation of cell surface death receptors. Cell 1998; 94: 481-490.

22. Li H, Zhu H, Xu CJ, Yuan J. Cleavage of BID by caspase 8 mediates the mitochondrial damage in the Fas pathway of apoptosis. Cell 1998; 94: 491-501.
23. Upton JP, Austgen K, Nishino M, Coakley KM, Hagen A, Han D et al. Caspase-2 cleavage of BID is a critical apoptotic signal downstream of endoplasmic reticulum stress. Mol Cell Biol 2008; 28: 3943-3951.

24. Bonzon C, Bouchier-Hayes L, Pagliari LJ, Green DR, Newmeyer DD. Caspase-2-induced apoptosis requires bid cleavage: a physiological role for bid in heat shock-induced death. Mol Biol Cell 2006; 17: 2150-2157.

25. Maas C, de Vries E, Tait SW, Borst J. Bid can mediate a pro-apoptotic response to etoposide and ionizing radiation without cleavage in its unstructured loop and in the absence of p53. Oncogene 2011; 30: 3636-3647.

26. Zinkel SS, Hurov KE, Ong C, Abtahi FM, Gross A, Korsmeyer SJ. A role for proapoptotic BID in the DNA-damage response. Cell 2005; 122: 579-591.

27. Uchida N, Friera AM, He D, Reitsma MJ, Tsukamoto AS, Weissman IL. Hydroxyurea can be used to increase mouse c-kit + Thy-1. 1(lo)Lin - /loSca-1 $(+)$ hematopoietic cell number and frequency in cell cycle in vivo. Blood 1997; 90: 4354-4362.

28. Spangrude GJ, Heimfeld S, Weissman IL. Purification and characterization of mouse hematopoietic stem cells. Science 1988; 241: 58-62.

29. Ogawa M. Differentiation and proliferation of hematopoietic stem cells. Blood 1993; 81 2844-2853.

30. Huntly BJ, Shigematsu H, Deguchi K, Lee BH, Mizuno S, Duclos N et al. MOZ-TIF2, but not BCR-ABL, confers properties of leukemic stem cells to committed murine hematopoietic progenitors. Cancer Cell 2004; 6: 587-596.

31. Wang J, Iwasaki H, Krivtsov A, Febbo PG, Thorner AR, Ernst $P$ et al. Conditional MLL-CBP targets GMP and models therapy-related myeloproliferative disease. Embo $J$ 2005; 24: 368-381.

32. Murga M, Bunting S, Montana MF, Soria R, Mulero F, Canamero M et al. A mouse model of ATR-Seckel shows embryonic replicative stress and accelerated aging. Nat Genet 2009; 41: 891-898.

33. Brown EJ, Baltimore D. ATR disruption leads to chromosomal fragmentation and early embryonic lethality. Genes Dev 2000; 14: 397-402.

34. Ruzankina Y, Schoppy DW, Asare A, Clark CE, Vonderheide RH, Brown EJ. Tissue regenerative delays and synthetic lethality in adult mice after combined deletion of Atr and Trp53. Nat Genet 2009; 41: 1144-1149.

35. Xu X, Vaithiyalingam S, Glick GG, Mordes DA, Chazin WJ, Cortez D. The basic cleft of RPA70N binds multiple checkpoint proteins, including RAD9, to regulate ATR signaling. Mol Cell Biol 2008; 28: 7345-7353.

36. Mordes DA, Glick GG, Zhao R, Cortez D. TopBP1 activates ATR through ATRIP and a PIKK regulatory domain. Genes Dev 2008; 22: 1478-1489.

37. Kamer I, Sarig R, Zaltsman Y, Niv H, Oberkovitz G, Regev L et al. Proapoptotic BID is an ATM effector in the DNA-damage response. Cell 2005; 122: 593-603.

38. Wang K, Yin XM, Chao DT, Milliman CL, Korsmeyer SJ. BID: a novel BH3 domain-only death agonist. Genes Dev 1996; 10: 2859-2869.

39. Liu Y, Vaithiyalingam S, Shi Q, Chazin WJ, Zinkel SS. BID binds to Replication protein A and stimulates ATR function following replicative stress. Mol Cell Biol 2011; 31: 4298-4309.

40. Ranger AM, Malynn BA, Korsmeyer SJ. Mouse models of cell death. Nat Genet 2001; 28: 113-118.

41. Cheng WC, Berman SB, Ivanovska I, Jonas EA, Lee SJ, Chen $Y$ et al. Mitochondrial factors with dual roles in death and survival. Oncogene 2006; 25: 4697-4705.

\section{Supplementary Information accompanies the paper on Cell Death and Differentiation website (http://www.nature.com/cdd)}

